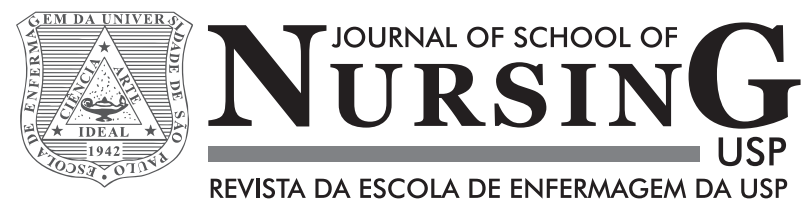

ORIGINAL ARTICLE

DOI: http://dx.doi.org/10.1590/S0080-623420160000600012

\title{
Nursing workload for cancer patients under palliative care
}

\author{
Carga de trabalho de enfermagem de pacientes oncológicos sob cuidados paliativos \\ Carga laboral de enfermería de pacientes oncológicos bajo cuidados paliativos
}

Patricia dos Santos Claro Fuly, Livia Márcia Vidal Pires², Claudia Quinto Santos de Souza², Beatriz Guitton Renaud Baptista de Oliveira1, Katia Grillo Padilha ${ }^{3}$

How to cite this article:

Fuly PSC, Pires LMV, Souza CQS, Oliveira BGRB, Padilha KG. Nursing workload for cancer patients under palliative care. Rev Esc Enferm USP. 2016;50(5):792-799. DOl: http://dx.doi.org/10.1590/S0080-623420160000600012

\footnotetext{
${ }^{1}$ Universidade Federal Fluminense, Niterói, RJ, Brazil.

${ }^{2}$ Instituto Nacional de Câncer José Alencar Gomes da Silva, Rio de Janeiro, RJ, Brazil.

${ }^{3}$ Universidade de São Paulo, Escola de Enfermagem, São Paulo, SP, Brazil.
}

\begin{abstract}
Objective: To verify the nursing workload required by cancer patients undergoing palliative care and possible associations between the demographic and clinical characteristics of the patients and the nursing workload. Method: This is a quantitative, cross-sectional, prospective study developed in the Connective Bone Tissue (TOC) clinics of Unit II of the Brazilian National Cancer Institute José Alencar Gomes da Silva with patients undergoing palliative care. Results: Analysis of 197 measures of the Nursing Activities Score (NAS) revealed a mean score of $43.09 \%$ and an association between the performance status of patients undergoing palliative care and the mean NAS scores. The results of the study point to the need to resize the team of the unit. Conclusion: The NAS has proven to be a useful tool in oncologic clinical units for patients undergoing palliative care.
\end{abstract}

DESCRIPTORS

Oncology Nursing; Workload; Palliative Care; Nursing Team; Personnel Administration; Hospital. 


\section{INTRODUCTION}

Connective and bone tissue tumors are usually known as bone sarcomas and soft parts sarcomas, respectively, as well as skin cancer. The incidence of the first occurs mainly in the second decade of life, during the periods of increased bone growth, such as the growth spurt during adolescence. The second (and less important) peak occurs in the sixth decade of life. Likewise, soft parts sarcomas occur in younger individuals and skin cancer has been affecting increasingly more people in tropical countries such as Brazil ${ }^{(1)}$. In view of these situations of threat to life, palliative care appears to relieve the suffering of the individual in its several dimensions through an approach to issues involving the availability of drugs for pain relief, training in palliative care for cancer, and establishment of national policies and programs that cover this theme. Advanced cancer generates a devastating burden of physical, emotional, and psychological symptoms ${ }^{(2)}$.

Nursing care to cancer patients undergoing palliative care requires emotional preparation on the part of the teams in view of the experiences of suffering of advanced cancer patients and their families ${ }^{(3)}$. The routine of care in view of the terminality generates emotional exhaustion in nursing professionals. The set of nursing interventions routinely implemented, combined with a paradigmatic rupture related to the non-curative aim of the treatment and the emotional and physical reactions of grief, are relevant elements in the management of the nursing team that works in palliative care. In addition to the emotional distress, it is also necessary to take into account that there is a work overload of nursing professionals, given the difficulty of managers to resize the human resources for palliative care ${ }^{(4)}$. The Resolution 293/2004, implemented by the Federal Council of Nursing (COFEN), which determines and establishes parameters to measure the nursing staff in health institutions, does not meet the specificity of these patients given the varied level of dependence of the patients and the demands of their family members ${ }^{(5)}$.

In view of these issues, the following objectives are identified in the present study: verification of the nursing workload required by cancer patients undergoing palliative care and the possible associations between the demographic and clinical characteristics of patients and nursing workload.

\section{METHOD}

The present study is a sub-project of the Casadinho UFF-USP Project approved in a call for proposals MCT/ CNPq/MEC/CAPE - Cross-sectional Action \#06/2011 -Casadinho/Procad: Innovation in Nursing in the treatment of tissue damage, systematization, technological inclusion, and functionality.

This is a quantitative, cross-sectional, prospective study developed in the Connective Bone Tissue (TOC) clinics of Unit II of the Brazilian National Cancer Institute José Alencar Gomes da Silva within the period from April to June 2014.
The mentioned unit treats clinical and surgical patients in infirmaries for gynecologic cancer. However, 10 beds of these infirmaries are exclusively for patients registered in the bone-connective tissue service, consisting of a subunit of TOC located on the fourth floor. The team that works in this infirmary has approximately seven members of the nursing staff per 12-hour shift: one head nurse (only during the morning shift), two nurses on duty, and four nursing technicians.

It is important to mention that patients with no current chance of healing are effectively assisted by the Clinical Oncology medical team while they wait to be transferred to Unit IV (Palliative Care). They receive comprehensive care from the team, with the exception of the non-adoption of invasive support measures in case of cardiopulmonary arrest. This is an institutional requirement according to the ethical and legal guidelines of the process of dying with dignity, and that also provides for the signature of a consent form of non-resuscitation by the legal guardian and/or the patient themselves. These guidelines are based on the bioethical principles of autonomy, beneficence, non-maleficence, and justice, and recommend methods to promote comfort and for palliative sedation of the patients under care at the final stage of life. Although in Brazil there is no legal support for non-cardiopulmonary resuscitation, in compliance with the code of ethics the doctor shall proceed with such indication. Transference to Unit IV depends on the current clinical condition, and occurs only when the possibility of death is not imminent during transportation.

The following eligibility criteria were adopted to make up the convenience, non-probabilistic sample: patients aged 18 years and over that had been hospitalized in the TOC clinics, regardless of the medical diagnosis, with a medical decision for palliative care registered in the medical record and a minimum length of stay of 24 hours.

Two instruments were used to collect data. The first one, made up of the characteristics of the patients, containing demographic data (age, sex, and marital status) and clinical data (types of tumor according to cell line: carcinoma; melanoma; and sarcoma); Charlson comorbidity index $(\mathrm{CCI})^{(6)}$; and functional capacity to perform common tasks according to the Karnofsky Performance Status (KPS) ${ }^{(7)}$ classification.

The KPS scale is a scoring system that enables the assessment of the functional capacity of patients through a decreasing scale of assessment of activities related to daily life. The scale ranges between $0 \%$ and $100 \%$, where $100 \%$ is associated with the absence of claims and/or evidence of the disease, while $0 \%$ is associated with death.

The CCI is a classification index that assigns scores to comorbidities, ranging between 0 and 6 points. The higher the CCI values, the higher the estimated risk of death of the patient. The final CCI is the sum of the scores assigned to each one of the clinical conditions described in the medical records ${ }^{(6)}$. 
The second instrument to collect data assessed the demand for nursing care required by patients under palliative care according to the NAS, an instrument to assess nursing care demands developed from the Therapeutic Interventions Score System, translated and validated in Brazil in $2003^{(8)}$. It is divided into seven major categories of interventions and presents a total of 23 items, measured with scores that, combined, represent the percentage of time spent by the nursing staff, in hours, in direct care to patients.

Demographic data, KPS, and comorbidities of each patient were extracted from the records based on the patients' medical charts; the CCI scores of each patient were calculated by the authors themselves.

Clinical data from the nursing records attached to the medical records of the patients related to the presence of tumor wounds, and characteristics varying in clinical staging were also extracted: 1 (intact skin); $1 \mathrm{~N} ; 2 ; 3$; and 4 , according to the Haisfield-Wolfe and Baxendale-Cox classifications ${ }^{(9)}$.

Data collection operationalization was conducted by two previously trained collectors. Every day during every 12 -hour shift relief they located the patients under palliative care in the infirmary through the records board of the unit.

The NAS record was obtained from the medical charts of the patients, as well as from information provided by nurses whenever necessary. At the end of the nurses' 12-hour shifts, the sum of the scores of each patient was calculated in order to achieve the total NAS values per 24 hours. The measures of NAS in incomplete 24-hour periods were disregarded.

All of the analyses were conducted in the software SAS, version 9.1.3. The results of the clinical demands of the patients were submitted to simple descriptive analysis, generating the NAS average, median, and standard deviation values. Descriptive statistics were conducted for the analysis of quantitative and qualitative variables. The Shapiro-Wilks normality test was conducted, followed by a simple linear regression analysis to evaluate the association between the NAS and the variables age, KPS, and length of stay. The Kruskal-Wallis test was applied for the variables type of cancer, presence of comorbidities, presence of wounds, and degree of wounds. The value $p<0.05$ was used as a pattern of significance for all tests.

The study was approved by the Research Ethics Committee of the National Cancer Institute José Alencar Gomes da Silva under the Protocol 504.332 on January 14, 2014.

\section{RESULTS}

\section{Characterization of the patients}

The sample of the study consisted of 29 patients undergoing palliative care in the TOC unit within the period of the study, resulting in 197 NAS measures. In relation to the types of tumors found in the patient sample, there was a predominance of sarcomas (55.17\%), followed by melanomas (41.37\%). Carcinomas were observed in $3.44 \%$ of the patients.
Table 1 - Demographic and clinical characteristics of patients hospitalized in the Connective Bone Tissue Unit. Rio de Janeiro, 2014.

\begin{tabular}{|c|c|c|}
\hline Variable & $\mathbf{N}$ & $\%$ \\
\hline \multicolumn{3}{|l|}{ Sex } \\
\hline Male & 18 & 62.07 \\
\hline Female & 11 & 37.93 \\
\hline \multicolumn{3}{|l|}{ Marital Status } \\
\hline Married & 16 & 55.17 \\
\hline Single & 7 & 24.14 \\
\hline Widowed & 2 & 6.90 \\
\hline Unmarried unions & 2 & 6.90 \\
\hline Common-law marriage & 1 & 3.45 \\
\hline Divorced & 1 & 3.45 \\
\hline \multicolumn{3}{|l|}{ Comorbidities } \\
\hline Yes & 17 & 58.62 \\
\hline No & 12 & 41.37 \\
\hline \multicolumn{3}{|l|}{ Wound } \\
\hline No & 24 & 82.76 \\
\hline Yes & 5 & 17.24 \\
\hline \multicolumn{3}{|l|}{ Death } \\
\hline No & 23 & 79.31 \\
\hline Yes & 6 & 20.69 \\
\hline
\end{tabular}

Note: $(n=29)$

The data in Table 1 show a predominance of male patients (62.07\%), married (55.17\%), with comorbidities (58.62\%), and without tumor wounds (82.76\%).

Regarding the comorbidities, it was observed that $12(41.37 \%)$ of the patients presented no comorbidities. Among the other 17 (58.62\%) patients presenting comorbidities, only seven presented two simultaneous comorbidities: five patients had systemic arterial hypertension (SAH) and diabetes mellitus (DM); one patient had SAH and stroke; and one patient had bronchitis and DM. The other 10 patients had a single comorbidity with the following distribution: seven patients had $\mathrm{SAH}$; one patient had only DM; one patient presented with sicklecell disease; and one had AIDS.

In relation to the staging of tumor wounds, five (17.24\%) patients were identified with different degrees of wounds: two with $1 \mathrm{~N}$ staging wounds; and three with staging 2, 3, and 4, respectively.

Regarding the discharge condition, most patients (23, $79.31 \%)$ survived, while six (20.69\%) died.

In relation to the quantitative data of the study, Table 2 introduces a descriptive analysis of the need for care and the demands of nursing work. 
Table 2 - Distribution of mean, standard deviation, median, and amplitude of the NAS score in patient admission and discharge of the Unit. Rio de Janeiro, Brazil, 2014.

\begin{tabular}{|c|c|c|c|c|c|c|}
\hline Variable & Mean & $\begin{array}{c}\text { Standard } \\
\text { Deviation }\end{array}$ & Median & Minimum & Maximum & Amplitude \\
\hline \multicolumn{7}{|l|}{ NAS } \\
\hline Admission & 49.73 & 9.66 & 49.00 & 30.00 & 69.9 & 39.90 \\
\hline Discharge & 64.07 & 17.89 & 57.70 & 44.9 & 108.9 & 64.00 \\
\hline
\end{tabular}

A mean NAS value of $43.09 \%$ was verified. At the admission of patients, the mean value was $49.73 \%$ (sd 9.66), the median was $49.00 \%$, and the amplitude (variation) was $39.9 \%$, while at discharge from the TOC unit (discharge/ death) the mean value was $64.07 \%$ (sd 17.89), the median was $57.70 \%$, and the amplitude (variation) was $64.00 \%$.

\section{FACTORS ASSOCIATED WITH NURSING WORKLOAD}

The results of the analyses of the association of the variables age, KPS, and length of stay with nursing workload are described below.

Table 3 - Test of the association of the quantitative variables with the NAS score. Rio de Janeiro, Brazil, 2014.

\begin{tabular}{lc}
\hline Variable & $\boldsymbol{p}$-value* \\
\hline KPS & $\mathbf{0 . 0 0 8 5}$ \\
Age & 0.1515 \\
Length of stay & 0.5660
\end{tabular}

*Simple linear regression

The data in Table 3 show that only the variable KPS presents an association with the NAS scores $(p=$ 0.0085 ). The other variables had no impact on the nursing workload.

Table 4 - Test of association of the qualitative variables with the NAS score. Rio de Janeiro, Brazil, 2014.

\begin{tabular}{lc}
\hline Variable & $\boldsymbol{p}$-value* \\
\hline Type of cancer & 0.2086 \\
Comorbidity index & 0.5159 \\
Presence of wounds & 0.9081 \\
Degree of the wounds & 0.6143 \\
Death & 0.1200 \\
\hline
\end{tabular}

*Kruskal-Wallis test

Regarding the variables type of cancer, comorbidity index, presence of wounds, degree of wounds, and death, Table 4 shows that none of the variables presents an impact on the nursing workload according to the NAS.

\section{Characterization of nursing interventions}

Table 5 shows the frequencies of nursing interventions undergone by patients during the 90 days of the study according to the NAS.
Table 5 - Frequency of therapeutic interventions according to the Nursing Activities Score. Rio de Janeiro, Brazil, 2014.

\begin{tabular}{|c|c|}
\hline NURSING ACTIVITIES SCORE INTERVENTIONS & $\%$ \\
\hline 1. Monitoring and controls & $100 \%$ \\
\hline $\begin{array}{l}\text { 2. Laboratory investigations: biochemical and } \\
\text { microbiological }\end{array}$ & $43.40 \%$ \\
\hline 3. Drug therapy, except for vasoactive drugs & $100 \%$ \\
\hline 4. Hygiene procedures & $91.75 \%$ \\
\hline $\begin{array}{l}\text { 5. Drain-related care-all } \\
\text { (except for gastric probes) }\end{array}$ & $10.98 \%$ \\
\hline 6. Mobilization and positioning & $63.18 \%$ \\
\hline 7. Support and care to patients and their families & $53.84 \%$ \\
\hline 8. Management and administrative tasks & $100 \%$ \\
\hline $\begin{array}{l}\text { 9. Respiratory support: any form of mechanical } \\
\text { ventilation/assisted ventilation; supplemental } \\
\text { oxygen by any method }\end{array}$ & $17.03 \%$ \\
\hline $\begin{array}{l}\text { 10. Care to artificial airways, endotracheal tubes, } \\
\text { or tracheostomy tubes }\end{array}$ & $0 \%$ \\
\hline $\begin{array}{l}\text { 11. Treatment to improve lung function: chest } \\
\text { physiotherapy; stimulated spirometry; inhalation } \\
\text { therapy; endotracheal aspiration }\end{array}$ & $0 \%$ \\
\hline $\begin{array}{l}\text { 12. Vasoactive medication, regardless of the } \\
\text { type and dosage }\end{array}$ & $0 \%$ \\
\hline $\begin{array}{l}\text { 13. Intravenous replacement of significant fluid } \\
\text { losses; fluid administration }>3 \mathrm{l} / \mathrm{m}^{2} / \text { day, regardless } \\
\text { of the type of fluid administered }\end{array}$ & $0 \%$ \\
\hline $\begin{array}{l}\text { 14. Monitoring of left atrium, with or without } \\
\text { cardiac debt measurement }\end{array}$ & $2.19 \%$ \\
\hline $\begin{array}{l}\text { 15. Cardiopulmonary resuscitation within the last } \\
24 \text { hours (except for precordial thump) }\end{array}$ & $0 \%$ \\
\hline 16. Hemofiltration techniques; dialysis techniques & $0 \%$ \\
\hline $\begin{array}{l}\text { 17. Quantitative measurement of urinary } \\
\text { output (ex.: indwelling urinary catheter) }\end{array}$ & $19.23 \%$ \\
\hline 18. Intracranial pressure measurement & $0 \%$ \\
\hline $\begin{array}{l}\text { 19. Treatment of complicated metabolic } \\
\text { acidosis/alkalosis }\end{array}$ & $1.64 \%$ \\
\hline 20. Intravenous hyperalimentation & $0 \%$ \\
\hline $\begin{array}{l}\text { 21. Enteral feeding, through a feeding tube or the } \\
\text { gastrointestinal tract (ex.: jejunostomy) }\end{array}$ & $9.34 \%$ \\
\hline 22. Specific interventions in the intensive care unit & $0 \%$ \\
\hline $\begin{array}{l}\text { 23. Specific interventions outside of the intensive } \\
\text { care unit; diagnostic or surgical procedures }\end{array}$ & $3.84 \%$ \\
\hline
\end{tabular}

Table 5 highlights that the following items: monitoring and control; medication except for vasoactive drugs; and management and administrative tasks were scored in 100\% of the patients. Hygiene procedures were scored in $91.75 \%$; mobility and positioning in 63.18\%; and support and care to patients and their family members were scored in $53.84 \%$ of the patients. 
The following items were scored in less than half of the patients: laboratory investigations: biochemical and microbiological; care with drains; respiratory support; monitoring of left atrium; quantitative measurement of urinary output; treatment of complicated metabolic acidosis/alkalosis; enteral feeding; and specific interventions outside of the intensive therapy unit.

Some items of the NAS did not score in any of the patients: care for artificial airways, endotracheal tube, or tracheostomy tube; treatment to improve lung function, chest physiotherapy, stimulated spirometry, inhalation therapy, and endotracheal aspiration; vasoactive medication, regardless of type and dosage; intravenous replacement of significant fluid losses, fluid administration $>31 / \mathrm{m}^{2} /$ day, regardless of the type of fluid administered; cardiopulmonary resuscitation within the last 24 hours (except precordial thump); hemofiltration techniques, dialysis techniques; intracranial pressure measurement; intravenous hyperalimentation; and specific interventions within the intensive therapy unit.

\section{DISCUSSION}

The data of the study point to a predominance of patients with sarcomas in the TOC clinics. Soft tissue sarcomas are a rare and heterogeneous group of malignant mesenchymal tumors, with about 50 histological subtypes, poor prognosis, and an average survival period of about one year in the case of metastatic disease ${ }^{(10)}$. They represent around $1 \%$ of the malignant tumors in adults and $15 \%$ in children; however they are more recurrent in adulthood, particularly in those over 50 years old ${ }^{(11)}$.

The estimation of new cases of cancer valid to 2014/2015 points to the occurrence of approximately 576,000 new cases; among these, melanoma has a low incidence (2,960 new cases in men and 2,930 in women); however its lethality is high. This type of skin cancer is less frequent than other skin tumors; it is more frequent in Caucasian populations exposed to solar radiation ${ }^{(12)}$. Its prognosis is good for localized tumors, while for metastatic melanomas the current therapies have not proven to be effective. Thus, early diagnosis and intervention are important to reduce mortality ${ }^{(13)}$.

The guarded prognosis for patients with advanced sarcomas and melanomas was corroborated in the findings of this study, taking into account that all of these patients were undergoing palliative care. This fact motivates a reflection on the need for early access to cancer treatment in the country, taking into account the healing potential of early diagnosed melanomas and sarcomas.

A study on delayed diagnosis and treatment of breast cancer ${ }^{(14)}$ points to problems in accessibility to the health network, varying from the first symptom to the medical consultation, from the first consultation to access to the reference service, and also from the first assessment by this service to the specific treatment. These problems have a direct impact on the modality of treatment and the possibility of healing. Sometimes the access to health services is so delayed that it implies advanced cancer, often with no possibility of healing. In such circumstances, the focus of the treatment is modified and palliative care is deliberated in the management of the disease.

The World Health Organization ${ }^{(15)}$ defines palliative care as an approach to the quality of life of patients and their families experiencing a disease that threatens life, preventing and relieving the suffering. Considering that the approach to the families of these patients is essential, the investigation of marital status of the patients revealed that $31.04 \%$ of them were single or widowed, requiring a concern for the care of these patients in their homes. Family is an important core in the formation of the beliefs, values, and knowledge of the individual, and in general the consequences of the illness are experienced by the whole family. Therefore, without a support network, the patient under palliative care undergoes excessive suffering, not only due to the disease itself, but also due to the absence of important people that may support their care at the end of life ${ }^{(16)}$.

The study revealed that nearly half the patients presented comorbidities, but only a quarter of them presented a high comorbidity index, indicating a low risk of associated death. Among these patients, only two died within the period of the study. No association of the CCI with the NAS was found. It is important to mention that in relation to the presence of comorbidities and their possible adverse consequences the literature indicates that they are an important prognostic factor for cancer patients, with relevant effects on the treatment and mortality of such patients ${ }^{(17)}$. Therefore, it is also important to take into account that, although this study has not corroborated the data found in the literature, the presence of comorbidities must affect the decision-making for the deliberation of palliative care in cancer patients.

The variable tumor wound results from the clear carcinogenesis process, consisting in a challenge for nursing management, particularly in relation to the minimization of the listed symptoms, with demands for control of odor, bleeding, exudation, pain, and itching ${ }^{(18)}$. Although the characteristics of the wounds vary in stages ${ }^{(8)}$ and they require different approaches to their inherent symptoms, no direct association was found between the workload and the tumor wound staging in patients under palliative care in the TOC. This fact may be associated with the reduced number of observations or even the clinical characteristics of the unit.

Regarding the performance status (KPS), an association between this variable and the NAS scores was observed. In other words, the lower the KPS value, the higher the mean NAS score within 24 hours. This finding is corroborated by the literature, as the KPS is considered a good instrument to predict the survival period of patients, taking into account the severity of the disease and quality of life ${ }^{(19,20)}$. The KPS is an important tool for clinical decision-making. 
The average NAS score was $43.09 \%$, with a mean value of $49.73 \%$ in admissions and $64.07 \%$ in discharge/death. These mean score values were lower than those observed in a series of studies published in the national literature conducted in $\mathrm{ICUs}^{(21-25)}$ and in a high-dependency unit $(51.47 \%)^{(26)}$. However, it was observed that in gastroenterology clinical and surgical hospitalization units ${ }^{(27)}$ the NAS values are lower (31.9\%) than those observed in the TOC unit, although the clinical-surgical characteristic prevails in both. Such a finding is related to the complexity of the patients undergoing palliative care, a group that expands the demand for nursing care beyond those expected for the unit. An approximation of the mean NAS value in the TOC unit to the values of studies conducted in a hospitalization unit $(47.31 \%)^{(28)}$ is observed.

A study that analyzed the association between nursing workload and nosocomial infection in the ICU found a high nursing workload with a higher average NAS score than other national studies (approximately 82.0\%)(29). However, the present study emphasizes the fact that the variable presence of infection was not considered for comparison purposes in patients undergoing palliative care, although this could affect the NAS score when the surgical profile of the unit as a whole is considered. The findings generate an important reflection on the definition of the number of professionals needed to work in the unit. Considering the mean NAS score obtained in this study and that each NAS point corresponds to 0.24 hours, an average of 10.34 hours of nursing care per patient was required within the 24 hours. The team assigned to the unit must serve not only the 10 patients in the TOC unit, but also the 26 patients in the clinical-surgical ward, implying work overload for the team. It is also observed that in the cases of discharge from the unit (death/discharge) the mean scores reach $64.07 \%$, indicating that nurses spend 15.37 hours per shift with only one patient. In specific cases of death the mean score reached $83.17 \%$, but the variable of death did not present a significant association with the NAS values when considering the small number of deaths within the period of data collection.

The variables type of tumor, age, comorbidity index, degree of wound, length of stay in the unit, and their possible associations with the NAS scores did not present significant results from a statistical perspective. In relation to the variables type of tumor, comorbidity index, and degree of tumor wounds, there is no available evidence allowing a comparison with the obtained results. In turn, the variable age and its independence in relation to the NAS scores corroborate results obtained in other studies ${ }^{(22,30)}$.

Regarding the results of the NAS sub-items, it was not possible to establish a comparison with other studies of the same nature, taking into account the specificity of the oncologic palliative care patients and the absence of publications using the NAS in oncology. However, it was observed that sub-items such as monitoring and controls, drug therapy, and management and administrative tasks were scored in $100 \%$ of the patients, indicating the need for supervision and care for these patients, as pointed out in other studies in intensive care units. In relation to the administrative tasks, the study emphasizes the time spent in guidance for family members regarding the deliberation around palliative care and its consequences until the transference to the unit VI of the INCA, which is specialized in this approach.

Some sub-items that were not scored may be explained by the uniqueness of the patients, as the KPS of the patient decreases proportionally to the increased need for invasive support, although patients undergoing palliative care have no clinical indication for this type of intervention. Although this fact contributes to reducing the NAS score of these patients, its application to such patients is emphasized.

There is a need for quantitative readjustment of the staff, as in the TOC unit the sizing took into account only its clinical-surgical characteristics, excluding some factors from the analysis such as the possible critical demands of the patients and the frequent number of hospitalizations of patients under palliative care; such circumstances generate a work overload for the team. One single patient under palliative care may require more than the full shift of a nurse due to the potential severity of their condition and demands for care by themselves and their family members as, in terms of palliative care, patients and family make up one treatment unit ${ }^{(2)}$.

\section{CONCLUSION}

The NAS was found to be a useful tool in oncologic clinical units for patients undergoing palliative care. The results point to only one association between the performance status of patients undergoing palliative care with the mean NAS values. The mean scores obtained in its implementation point to a work overload of nursing, although nine of its sub-items were not scored by any of the patients. The NAS scores of the patients in the TOC unit undergoing palliative care were close to several values reported in the literature for patients in clinical and surgical hospitalization units. The findings point to the need to review the staff in the unit, considering that the established sizing does not take into account the specific demands of patients undergoing palliative care who are hospitalized in the clinical and surgical beds of the TOC clinics, as there are also the demands of the other patients undergoing adjuvant and neoadjuvant therapy who are also hospitalized in the unit.

In addition to the absence of published national and international studies with an association of oncologic patients and workload according to the NAS, the reduced size of the sample and the fact that the study was conducted in one single oncologic clinical unit that was not specialized in palliative care represent limitations of the study. This hampers a comparison of these results with specific populations, despite the association between the NAS. Other populations that are not exclusive to intensive care may be perceived through the aforementioned studies 
RESUMO

Objetivo: Verificar a carga de trabalho de enfermagem requerida por pacientes com câncer sob cuidados paliativos e possíveis associações entre as características demográficas e clínicas dos pacientes e a carga de trabalho de enfermagem. Método: Trata-se de um estudo de abordagem quantitativa, transversal, prospectivo, desenvolvido na clínica de Tecido Ósseo Conectivo (TOC) da Unidade II do Instituto Nacional de Câncer José Alencar Gomes da Silva, com pacientes em cuidados paliativos. Resultados: A análise de 197 medidas do Nursing Activities Score (NAS) revelou um escore médio de 43,09\% e uma associação entre a performance status de pacientes em cuidados paliativos com os valores médios do NAS. Os resultados do estudo apontam para a necessidade de redimensionamento da equipe da Unidade. Conclusão: O NAS mostrou-se um instrumento passível de utilização em unidades clínicas oncológicas, com pacientes em cuidados paliativos.

\section{DESCRITORES}

Enfermagem Oncológica; Carga de Trabalho; Cuidados Paliativos; Equipe de Enfermagem; Administração de Recursos Humanos em Hospitais.

\section{RESUMEN}

Objetivo: Verificar la carga laboral de enfermería requerida por pacientes con cáncer bajo cuidados paliativos y posibles asociaciones entre las características demográficas y clínicas de los pacientes y la carga laboral de enfermería. Método: Se trata de un estudio de abordaje cuantitativo, transversal, prospectivo, desarrollado en la clínica de Tejido Óseo Conectivo (TOC) de la Unidad II del Instituto Nacional de Cáncer José Alencar Gomes da Silva, con pacientes en cuidados paliativos. Resultados: El análisis de 197 medidas del Nursing Activities Score (NAS) reveló un puntaje medio del 43,09\% y una asociación entre el performance status de pacientes en cuidados paliativos con los valores medios del NAS. Los resultados del estudio señalan la necesidad de redimensionamiento del equipo de la Unidad. Conclusión: El NAS se mostró un instrumento pasible de utilización en unidades clínicas oncológicas, con pacientes en cuidados paliativos.

\section{DESCRIPTORES}

Enfermería Oncológica; Carga de Trabajo; Cuidados Paliativos; Grupo de Enfermería; Administración de Personal en Hospitales.

\section{REFERENCES}

1. Conley A, Trent JC. Sarcomas de partes moles. In: Hoff PMGP, editor. Tratado de oncologia. São Paulo: Atheneu; 2013. p. 2809.

2. Instituto Nacional do Câncer José Alencar Gomes da Silva. Cuidados paliativos [Internet]. Rio de Janeiro: INCA; 2014 [citado 2014 jul. 22]. Disponível em: http://www1.inca.gov.br/conteudo_view.asp?ID=474

3. Almeida CSL, Sales CA, Marcon SS. The existence of nursing in caring for terminally ills life: a phenomenological study. Rev Esc Enferm USP [Internet]]. 2014 [cited 2014 July 22];48(1):34-40. Available from: http://www.scielo.br/pdf/reeusp/v48n1/00806234-reeusp-48-01-34.pdf

4. Silva MM, Moreira MC, Leite JL, Erdmann AL. Nursing work at night in palliative oncology care. Rev Latino Am Enfermagem [Internet]. 2013 [cited 2014 July 22];21(3):773-9. Available from: http://www.scielo.br/pdf/rlae/v21n3/0104-1169-rlae-21-03-0773.pdf

5. Conselho Federal de Enfermagem. Resolução COFEn-293/2004. Fixa e estabelece Parâmetros Para o Dimensionamento do Quadro de Profissionais de Enfermagem nas Unidades Assistenciais das Instituições de Saúde e assemelhados [Internet]. Brasília: COFEn; 2004 [citado 2014 dez. 12]. Disponível em: http://www.cofen.gov.br/resoluo-cofen-2932004_4329.html

6. Charlson ME, Pompei P, MacKenzie CR. A new method of classifying prognostic comorbidity in longitudinal studies: development and validation. J Chronic Dis. 1987; 40(5):373-83.

7. Karnofsky DA, Burchena JH. The clinical evaluation of chemotherapeutic agents in cancer. In: Macleod CM. Evaluation of chemotherapeutic agents. New York: Columbia University; 1949. p.199-205.

8. Queijo AF, Padilha KG. Nursing Activities Score (NAS): cross-cultural adaptation and validation to Portuguese language. Rev Esc Enferm USP. 2009;43(n.spe):1018-25.

9. Haisfield-Wolfe ME, Baxendale-Cox LM. Staging of malignant cutaneous wounds: a pilot study. Oncol Nurs Forum.1999;26(6):1055-64.

10. Van der Graaf WT, Gelderblom H . New systemic therapy options for advanced sarcomas. Curr Treat Options Oncol. 2012;13(3):306-17.

11. Ducimetière F, Lurkin A, Ranchère-Vince $D$, Decouvelaere AV, Pèoc'h $M$, Istier L, et al. Incidence of sarcoma histotypes and molecular subtypes in a prospective epidemiological study with central pathology review and molecular testing. PLoS One 2011;6(8):e20294.

12. Instituto Nacional de Câncer José Alencar Gomes da Silva; Coordenação de Prevenção e Vigilância. Estimativa 2014: incidência de câncer no Brasil. Rio de Janeiro: INCA; 2014.

13. Silva VPM, Nunes DH, Ikino JK, Giunta GD, Sens MM. Características dermoscópicos de melanomas finos: um estudo comparativo de melanoma in situ e melanomas invasivos menores ou iguais a 1 mm. Anais Bras Dermatol. 2013;88(5):712-7.

14. Trufelli DC, Miranda VC, Santos MBB, Fraile NMP, Pecoroni PG, Gonzaga SFR, et al. Análise do atraso no diagnóstico e tratamento do câncer de mama em um hospital público. Rev Assoc Med Bras. 2008;54(1):72-6.

15. World Health Organization. National Cancer Control Programmes. Policies and managerial guidelines. 2nd ed. Geneva: WHO; 2001.

16. Inocenti A, Rodrigues IG, Miasso AI. Vivências e sentimentos do cuidador familiar do paciente oncológico em cuidados paliativos. Rev Eletr Enf [Internet]. 2009 [citado 2015 maio 16];11(4):858-65. Disponível em: https://www.fen.ufg.br/fen_revista/v11/n4/pdf/v11n4a11.pdf

17. Smith AW, Reeve BB, Bellizzi KM, Harlan LC, Klabunde CN, Amsellem M, et al. Cancer, comorbidities, and health-related quality of life of older adults. Health Care Financ Rev. 2008;29(4):41-56.

18. Probst S, Arber A, Faithfull S. Malignant fungating wounds: the meaning of living in an unbounded body. Eur J Oncol Nurs. 2013;17(1):38-45. 
19. Fairchild A, Debenham B, Danielson B, Huang F, Ghosh S. Comparative multidisciplinary prediction of survivor in patients with advanced cancer. Support Care Cancer.Comparative multidisciplinary prediction of survival in patients with advanced cancer. 2014;22(3):611-7.

20. Lam K, Chow E, Zhang L, Wong E, Bedard G, Fairchild A, et al. Determinants of quality of life in advanced cancer patients with bone metastases undergoing palliative radiation treatment. Support Care Cancer. 2013;21(11):3021-30.

21. Nogueira LS, Koike KM, Sardinha DS, Padilha KG, Sousa RMC. Nursing workload in public and private intensive care units. Rev Bras Ter Intensiva. 2013;25(3):225-32.

22. Leite IRL, Silva GRF, Padilha KG. Nursing Activities Score and demand of nursing work in intensive care. Acta Paul Enferm. 2012;25(6):837-43.

23. Coelho FUA, Queijo AF, Andolhe R, Gonçalves LA, Padilha KG. Carga de trabalho de enfermagem em Unidade de Terapia Intensiva de Cardiologia e fatores clínicos associados. Texto Contexto Enferm. 2011;20(4):735-41.

24. Padilha KG, Sousa RMC, Garcia PC, Bento ST, Finardi EM, Hatarashi RHK. Nursing workload and staff allocation in an intensive care unit: a pilot study according to Nursing Activities Score (NAS). Intensive Crit Care Nurs. 2010;26(2):108-13.

25. Queijo AF, Martins RS, Andolhe R, Oliveira EM, Barbosa RL, Padilha KG. Nursing workload in neurological intensive care units: crosssectional study. Intensive Crit Care Nurs. 2013;29(2):112-6.

26. Lima MKF, Tsukamoto R, Fugulin MFT. Aplicação do Nursing Activities Score em pacientes de alta dependência de enfermagem. Texto Contexto Enferm. 2008;17(4): 638-46.

27. Panunto MR, Guirardello EB. Nursing workload at a gastroenterology unit. Rev Latino Am Enfermagem. 2009;17(6):1009-14.

28. Brito AP, Guirardello EB. Nursing workload in na intensive care unit of a teaching hospital. Rev Latino Am Enfermagem. 2011;19(5):1139-45.

29. Daud-Gallotti RM, Costa SF, Guimarães T, Padilha KG, Inoue EM, Vasconcelos TN, et al. Nursing workload as a risk factor for healthcare associated infections in ICU: a prospective study. Plos One. 2012;7(12):e52342.

30. Gonçalves LA; Padilha KG. Fatores associados à carga de trabalho de enfermagem em Unidade de Terapia Intensiva. Rev Esc Enferm USP. 2007;41(4):645-52.

Financial support: National Council for Scientific and Technological Development (CNPq). Protocol \# 552664/2011-1. Grant of Junior Postdoctoral Scholarship-PDJ of Patrícia dos Santos Claro Fuly, Protocol \# 151502/2013-7. 